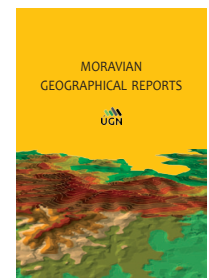

The Czech Academy of Sciences, Institute of Geonics

journal homepage: http://www.geonika.cz/mgr.html

doi: https://oi.org/10.2478/mgr-2020-0023

\title{
To fear or not to fear? Exploring the temporality of topophobia in urban environments
}

\author{
Petr ŠIMÁČEK a *, Miloslav ŠERÝ a , David FIEDOR ${ }^{\text {a }}$, Lucia BRISUDOVÁ a
}

\begin{abstract}
The concept of topophobia has been known in Geography for decades. Places which evoke fear in people's minds can be found in almost every city. The perception of fear within an urban environment shows a certain spatio-temporal concentration and is often represented by fear of crime. The meaning of topophobic places, however, derived from the experience of fear of crime changes over time, and thus can alter the usual patterns of population behaviours in relation to time (in the time of the day and over longer periods) and space. A spatiotemporal understanding of these changes is therefore crucial for local decision-makers. Using data from the Czech Republic, this paper deals with the analysis of topophobic places, and is based on an empirical survey of the inhabitants of four cities, using the concept of mental mapping. In contrast to most similar geographical studies, the paper emphasises the temporal dimension of the fear of crime. The results have shown that over time there are significant differences in the meanings of topophobic places, and they have demonstrated the necessity of taking local specifics into account. The paper shows how the intensity of and the reasons for fears vary, depending on time and place. In general, the results provide support for the idea of place as a process and contain useful information for spatial planning and policy in urban areas.
\end{abstract}

Keywords: temporality; fear of crime; topophobia; mental maps; meaning of place; Czech Republic

Article history: Received 17 April 2020, Accepted 11 November 2020, Published 31 December 2020

\section{Introduction}

For decades, safety has generally been considered one of the basic human needs (Maslow, 1943). One's feelings of safety can be disturbed by many elements and one of them is undoubtedly the fear of crime. With respect to the reduced feelings of safety which stem from fear of crime, the changes in an individual's decision making and behaviour occur in both space and time. Those concerns are subjective to a considerable extent and dependent on many aspects of human life. Therefore, every individual can feel a different intensity of danger in a particular environment. Moreover, fear of crime is currently perceived as a serious society-wide issue (Hale, 1996; Salem and Lewis, 2016) and as such it has become the topical subject of much scientific research. (e.g. in economics: Bannister and Fyfe, 2001; in psychology: Gabriel and Greve, 2003; or in criminology: Gray et al., 2011).

Research on the fear of crime fundamentally discuss the issue from two main perspectives. The first deals with population views and socio-demographic profiles. Regarding this aspect, it is important to emphasise the differentiated and oft-examined perception of fear on the basis of gender
(Pain, 2001; Tandoğan and Topçu, 2018) and age group (AduMireku, 2002; Clememte and Kleiman, 1976). Furthermore, there are studies which focus on the fear of crime as felt by people of diverse social status. To illustrate this, there can be social segregation within socially diverse residential districts. This can lead to the so-called 'gated communities', where only each particular district's residents can gain access (Sakip et al., 2018; Tomášek, 2010; Tulumello, 2015). For these studies that deal with the fear of crime based on population perceptions, there are works based on distinguishing the extent of fear of crime among both native and immigrant inhabitants (as in Canada - Weinrath, 2000; and Denmark Glas et al., 2019).

A second perspective focuses on the meaning of the physical environment as a determining factor in the fear of crime. Such papers seek to clarify the safety/hazardousness of municipal parks and public green places from the points of view of those affected by fear of them (Jim and Chen, 2006; Suau and Confer, 2006). Another aspect that Atkins et al. focused on in their study (1991) is street lighting, also with connections to the fear of crime. Cozens

\footnotetext{
a Department of Geography, Faculty of Science, Palacký University Olomouc, Czech Republic (*corresponding author: P. Šimáček, e-mail: petr.simacek@upol.cz)
} 
et al. (2003) likewise highlight typical locations in urban spaces (explicitly train stations and their surroundings), whose physical appearance often causes unpleasant feelings, and which can lead to people repeatedly referring to the locations as 'places of fear'.

Geography, then, plays a significant role in research into the concept of fear of crime (see e.g. Stasíková, 2011), because such fears can be seen as experiences which are always connected with particular places. Owing to such experiences, a place gains identity and this meaning can influence people's spatial behaviour. Because of the close interconnection between fear of crime and place, some geographers (e.g. Little et al., 2005; Pain, 1997 and 2000) have tried to find specific rules, or rather patterns, in this relationship.

Most of these studies, however, rarely mention one important variable which significantly forms the perceptions of a place: time and its dynamics. The need for a common adjustment of time and space is emphasised in the work of Ellegård (2019, p. 3), who highlights the "importance of taking time and place into consideration when reflecting on and investigating human activity". Despite the fact that there are observations of the fear of crime or of crime itself, partially interpreted with regard to temporal (Solymosi et al., 2015) or seasonal (Andresen and Malleson, 2013) circumstances, there is no sufficient framing of this concept in time. In this paper, we would like to address this shortcoming.

Based on data from the Czech Republic, the main aim of this contribution is to explore and identify the spatial and, more particularly, the temporal dimensions of fear of crime, understood as a specific urban experience that informs the negative meaning of a place. For this purpose, several research questions $(\mathrm{RQ})$ were established:

- RQ1: Is it possible to discover relevant changes in some identified places over a long period of time, on the basis of lived space-time experience?;

- RQ2: Is it possible to discover relevant changes in the identified places during the day, on the basis of everyday space-time experience?; and

- RQ3: What are the most common reasons for the perceived fears, and are there differences in their structure in space and time?

Our research employs three approaches: first, place as a process and as a constantly human product (Pred, 1984); second, topophobia as the expression of negative meanings of a place (Tuan, 1975); and third, time geography (Ellegård, 2019). Fear of crime as such is always set to a specific place and time, both of which help to identify the consequences and context, and because of that a deeper analysis of issues connected to fear of crime can be carried out. We grasp place as an entity that always represents a human product (Pred, 1984), and as an entity of individually felt significance, values and meanings (Tuan, 1977). The temporality of place is also considered in order to understand time dynamics (see e.g. Hägerstrand, 1983, or Mulíček et al., 2015). According to Ellegård (2019, p. 3) the "timegeographic approach ... helps in analysing how one and the same need is satisfied differently depending on where, when and by whom the activities are performed". Therefore, time geography creates a convenient "tool through which it is possible to reveal the phenomena and relationships in everyday life" (Ira, 2001, p. 243).

As stated by Jíchová and Temelová (2012), it is not only criminality itself but also the population's perception of fear of crime, which are important topics with potential impacts on the policies of municipalities. Therefore, monitoring the presented phenomenon in space and time can help in the decision-making sphere by, for example, producing conceptual documents focused on precautions against criminality and on urban development. If the correct identification of a problem is accomplished, it is possible to focus the potential precautions more precisely and effectively (with regard to space, time and phenomena) in order to rectify situations in problematic locations.

\section{Theoretical frame of the research}

In this theoretical section of the article we introduce and elaborate on the principal concepts related to the research. We commence with the concept of place, not omitting the problematics of spatiality and temporality. We then focus on people's experiences of place and the effect of those experiences on the creation of meanings attributed to that place. Subsequently, the relationships between place, experience, meaning and time are discussed. This is followed by a basic typology of the meanings of place, and the role of crime on the meanings of place is also discussed. In the final part of this section we discuss such matters as how the negative meanings of places can affect human behaviours within urban settlements, and the policy implications of knowing about places that have been attributed with negative meanings based on the fear of crime.

\subsection{Place, experience, meaning and time}

Place is one of the key geographical concepts. Despite this, there is no general acceptance of the understanding of place amongst geographers. For example, Malpas (2018) states that place is often taken for granted. On the other hand, it is a challenge to find a detailed analysis of the concept of place. Thus, we lack a widely acknowledged definition of place. Instead, according to Paasi (2002, p. 806), place is, in geographical language, conceptualised flexibly, and a definition depends on the context to which a place is related, while also emphasising the aspect of local scale that has for many years fuelled the general understanding of place. A different way to approach the concept of place is elaborated by humanistic geographers, who have not fixed place on to any scale. Rather, they have emphasised the importance of human experience for an understanding of place. Experience plays a key role in the process of attributing meaning to a place, since experience drives the process (Daněk, 2013). A meaningful place as such cannot be understood as a simple physical location, since it can be conceptualised as a constantly human product (Pred, 1984). Thus, when analysing the spatiality of a place one also has to consider the socially constructed dimensions of that place. For instance, Tuan (1977) conceptualised place as an organised world of meaning and added that space is transformed to place when it gains definition and meaning. As well, Relph (1976) sees place as a result of the spatial concentration of human actions, experiences and intentions.

An urban place should be defined not only through its spatial attributes and social dimensions, but also through time. In his seminal contribution, Pred (1984, p. 279) rejects the idea of place as a static entity "that emerges fully formed out of nothingness and stops, grows rigid, and is indelibly etched into the once-natural landscape". Rather, he employs the temporal dimension which emphasises place as a process. Cresswell (2008) also addresses the aspect of time when he discusses the temporality of place. In other words, the affiliation of a place to a particular spatio-temporal system 
should also be taken into account (Mulíček et al., 2016). In relation to time, two conceptualisations could be employed: first, linear time or the one-way flow of time; second, cyclical time or the cyclical flow of time.

Linear time is a form of mechanical clock-time not anchored in spatial, social or economic activities (Golledge and Stimson, 1997; Mulíček et al., 2015). With respect to linear time, a place is seen as a pause in time instead of an unchanging reality (Liu and Freestone, 2016). A place serves as a container of linear time: personal memories and biographies are bounded in a specific place, where the life paths of specific people take place (Pred, 1984). As a consequence, there are experiences from past times sedimented in a place, because it is in that place that these experiences are spatialised, materialised and memorialised. The idea is broadly discussed by Malpas (2018, p. 184), who states: "The past cannot be grasped independently of place. Only in place can there be a creature capable of grasping past, present or future, and only within the compass of place can there be the spatio-temporal ordering of things on which a grasp of the past depends".

The second conceptualisation of time, cyclical time, is not understood as being in binary opposition to linear time. Rather, it is complementary to linear time, as cyclical time also determines the temporality of a place. Cyclical time draws on the repetition of spatial actions by human beings and on their routines (Crang, 2011; Golledge and Stimson, 1997). These are organised at various frequencies, such as on a daily, weekly, monthly or yearly basis. Repetitive actions and routines expressing cyclical time are necessarily bonded to particular places, spatially localised entities, objects and processes. This is especially true concerning routes used daily, conceptualised by Pred (1984, p. 281) as set of "actions and events consecutively making up the existence of an individual". Hence, both concepts of time define the temporality of a place that is not merely characterised by its spatiality. From this point of view, a place becomes a unit of time-space.

Gaining knowledge about a place could also be seen as a function of time, since it requires some period of time to acquire that knowledge (Tuan, 1977). This acquisition is made up of a large amount and a wide range of experiences that have occurred over years (linear time), and which have also been reproduced and transformed day after day, week after week, etc. (cyclical time). The learning about places and subsequently assessing them through experiences with them is accumulated, reproduced and transformed over time, and this leads to the different meanings that humans attribute to certain places, whereby these meanings are reproduced (sedimented) and transformed (changed). Tuan (1975) defined two basic categories in assessing the importance of a place. The first is topophilia, the second is topophobia. A topophilic place has positive meanings so it is seen as a safe, pleasant, popular and desirable place. On the other hand, a topophobic place is connected with negative meanings and so it is subsequently understood to be dangerous, unpleasant and repulsive, and is consciously avoided. It is possible in many cases for both these contrasting meanings to be contained within one place. Accordingly, a third type of place importance can be added, complementary to the two mutually dichotomous categories. This can be defined as topo-ambivalence (Brisudová et al., 2020), based on the duality of a place. Positive and negative meanings attributed to various places, even to one specific place, originate from the experiences gained over time by individual residents, i.e. from people who differ in such socio-demographic factors as gender, age, social class, education and length of residence (Golledge and Stimson, 1997). Beside time, these factors also influence the character of the meanings attributed to particular places.

\subsection{Fear of crime as a specific experience of an urban place}

Fear of crime is one of the urban experiences that essentially determine the negative meaning of place. Urban residents may fear certain places and this could be due to past and recent events (e.g. violent attacks in a certain place) sedimented in their biographies, current and past physical appearances of a place (e.g. brownfields), and information from secondary sources such as media and conversations with other people. Fear of crime can be both rational, corresponding with real crime, and irrational, not reflecting the actual crime situation (Bannister and Fyfe, 2001). This raises the question of which aspects mainly determine that the fear of crime is experienced in a particular place. Ceccato (2020a, p. 24) emphasises the importance of people's individual characteristics: physical and psychological abilities, gender, age, ethnicity, sexual, social and economic statuses are named. Previous research (e.g. Pain and Smith, 2008) has provided evidence suggesting that women, the elderly, members of ethnic minority groups, those who belong to the LGBTQI (i.e. lesbian, gay, bisexual, transgender/transsexual, queer/questioning and intersexed) community, and the disabled and disadvantaged, are more prone to experience fear of crime more intensively.

All in all, when one thinks about fear of crime, the intersection of multiple individual factors has to be thoroughly considered (Pődör et al., 2016). Beside individual aspects, the environmental structure of urban places must also be taken into account, since it underpins fear (Cozens and Love, 2015; Shamsuddin and Hussin, 2013). Loukaitou-Sideris (2009) identifies dark environments, poor guardianship, lack of maintenance, physical and social disorder and unkempt and abandoned buildings, as important environmental entities contributing to higher levels of fear of crime being attributed to places. Ceccato (2020b, p. 39) adds that "poor maintenance or signs of physical deterioration of an area are thought to be more important determinants of fear of crime than the actual incidence of crime". Both physical and social disorder and its forms in an urban environment are described as elements of the 'disorder/incivilities' hypothesis, which points to different forms of incivility which are perceived to be warning signs of a potential criminal threat leading to fear of crime (Doran and Burgess, 2011, p. 38).

Fear of crime, as well as any other urban experience, develops over time. The temporal dimensions of fear of crime can be approached through a broader process of ceaseless reproduction of social and cultural forms, the formation of biographies and the reproduction and transformation of the physical structure of place (see Pred, 1984). The oneway reproduction or transition of physical appearance and long-term path-projects in urban places defines linear time. That is why the fear of crime can differ between generations, and length of residence in urban space can also affect the intensity of fear of crime (Andreescu, 2013; Glas et al., 2019). The regular repetition of physical appearance and shortterm path-projects define cyclical time. Hence, the intensity of fear of crime can be determined by the regularly changing phases of the day (Jíchová and Temelová, 2012; Pantyley et al., 2017), week (weekdays, weekend dichotomy) or season 
(Semmens et al., 2002). As a result, both complementary conceptualisations of time can influence the reproduction, transformation and disappearance of fear of crime in one particular urban place.

People respond to the fear of crime in various ways. Among other responses, Grohe et al. (2012) described the following important reactions: residents may avoid certain places at particular times and may modify their daily routines and lifestyles, or they may generally withdraw from participation in urban life. As early as fifty years ago, Stuart (1969) similarly evidenced the ability of fear of crime to force residents to change their ways of life, more specifically to abandon large parts of American cities and change their 'natural' patterns of behaviour. Moreover, in addition to the viability of neighbourhoods, it is acknowledged that behavioural responses to the fear of crime impact on physical and mental health (Curtis, 2012; Latkin and Curry, 2003). All responses are accompanied by changes in the spatial and temporal dimensions of the behaviours of urban residents. The spatiality and temporality of the behaviour of urban residents can be seriously affected and altered by their responses to the fear of crime attributed to particular urban places, and all changes in the spatial behaviour of urban residents can consequently underpin a decrease in the quality of life and overall well-being within an urban space.

It is important to realise that crime and the fear of crime are two qualitatively different phenomena (Minnery and Lim, 2005). Based on previous research (Doran and Burgess, 2011, p. 190; Ivan et al., 2020) it can be declared that there is a close relationship between the fear of crime and real crime cases. On the other hand, the presence and spatial distribution of topophobic places based on the fear of crime does not necessarily correspond to the level of real crime. Tulumello (2015, p. 258) points out that "all across the Western world violent crime rates have being dropping dramatically since the early 1990 s, at the same time as fear of crime has been growing to the highest levels ever recorded". Hanslmaier (2013) emphasises the important impact of (especially local) media and social networks when considering fear of crime, as it presents information about local crime and other incidents which could then develop a fear of a particular place. Although the occurrence and spatial deployment of topophobic places based on the fear of crime does not always have to correspond to the level of real crime, it could be used as a valuable and practical tool for the identification of problematic places within an urban space (Lopez and Lukinbeal, 2010).

The identification of topophobic places as determined by the fear of crime, as well as an understanding of their physical structure and a thorough knowledge of the topophobic meanings of those places caused by a fear of crime, have policy implications as does the role played by the temporality of these meanings. The topophobic meaning of a place fueled by fear of crime can be reduced through improved planning and policing, which should result in the sustainable spatial behaviour of urban residents. In a more general way this idea is formulated by Marshall (2016, p. 201). In her contribution she makes the following concluding points: "City-makers such as planners, landscape architects, architects, and politicians need to understand people and their civic relationship to open space and facilitate their public life. This ultimately improves the physical urban amenity and the social sustainability of the $21^{\text {st }}$ century city". Urban safety, described by Ceccato and Lukyte (2011) as a dimension of urban sustainability, is an ongoing process that could also be improved through appropriate urban planning approaches. There is a range of techniques that contribute to the needs of contemporary urbanism (Tulumello et al., 2017). One of them is Crime Prevention Through Environmental Design (CPTED), which aims to provide a safer urban environment. This concept has already been implemented in many cities and should lead to a reduction in fear of crime and a strengthening of the sustainability of cities (Cozens and Love, 2015; Shamsuddin and Hussin, 2013). Information about the spatial deployment of places perceived in the context of fear of crime undoubtedly have a valuable character. The advantages of knowing about fear of crime hot spots for urban development purposes have been positively evaluated, as in the Community Safety Mapping Project in Sydney (Doran and Burgess, 2011, p. 221). Through avoidance maps created by the residents' perceptions/fear of crime, the police identified new areas of disorder that were previously unknown.

\section{Data and methods}

\subsection{Methodological points of departure and the methods of research}

Our research is grounded in the concept of mental maps, which are the result of perception processes. More precisely, we employed the narrowed problematics of perception that are used in geography (Siwek, 2011). Conceptualised as such, it is understood to be the perception of space. For our contribution we draw upon a definition by Golledge and Stimson (1997, p. 190) who wrote that perception is the immediate apprehension of information about the environment. This primarily happens via one or more of the senses. Secondary environmental information is taken from the media and through hearsay via communication with fellow humans. When thinking about perceptions one should also include matters of collective cultural beliefs, values and aesthetic judgments related to the natural and human-made environments (Wills, 2009). Thus, in the case of perception, it is a consequence of mental activity that arises from the registration of actual environmental stimuli and the art of imagination. The images resulting from this process are stored in the human mind and are recalled as needed by the individual. It is the circumstances in which arise the need to use the concept that shape its actual form.

One of the above-mentioned images could be mental maps (Gould and White, 2005; Tuan, 1975) resulting from the processes of perception. Mental maps can be understood as a construct arising from internal psychological processes. External influences, however, cause this construct to be a complex formation also to have a significant influence on the form of the mental map. Mental maps are important because of their features. Most importantly, mental maps serve as sources of information for decision-making processes, which affect the spatial behaviours of people within the environment (Lloyd, 1989). Besides, mental maps can be understood as a kind of memory device that enables people to carry out common mental practices that promote self-confidence in subsequent physical actions (Tuan, 1975). Last, but not least, their other function is the ability to be focused on geographic knowledge. Just as 'real' maps are a means of structuring and storing knowledge in memory, mental maps are a means of organising spatial data. According to Tuan (1975), mental maps can serve geographers as the cartographic representation of peoples' attitudes toward places. 
From the methodological point of view, mental mapping is generally considered a practical research method in geographical environmental perception (Gould and White, 2005; Pánek, 2016). According to Frantál et al. (2017, p. 238) "mental mapping is a valuable tool for understanding how humans perceive and reflect their environment". The convenience of the mental mapping application in data collection from urban space research has been demonstrated in case studies from all over the world, regardless of the type of research: it can be a systematic way to study the meanings of places (Osman, 2016); an expansion of creative industry in a city (Brennan-Horley, 2010); a contribution from its inhabitants to a city's development (Ghioca, 2014); or the identification of places identified as causing fear (Curtis, 2012).

Mental maps should be understood as a general concept. When emotion and its spatial context become the object of imaging or drawing, such mental maps are called emotional maps (Perkins, 2009). According to Pánek (2018, p. 19) "emotional maps are a spatially accurate mode of data collection and use a base map as a background for respondents' drawings". Through an emotional map, an individual is able to visualise images of places to which she/he attributes certain emotions and meanings from her/his own (or mediated) experiences. The mental map (in the form of an emotional map) was thus chosen as a suitable tool for obtaining information about places which produce a fear of crime - not only about their location, but also about their other attributes (e.g. causes of fear or times when people felt fear in a place).

\subsection{Case study area}

The Czech Republic has long been considered one of the safest countries in the world (Institute for Economics and Peace, 2020). Despite this, it is important to evaluate feelings of fear of crime because they influence and, to some extent, contribute to the overall quality of life. For the present study, a case study area was determined as the territories of the four largest cities in the Olomouc Region. The Olomouc Region is one of fourteen NUTS3 units in the territory of the Czech Republic and is situated in the eastern part of the country (see Fig. 1). The four cities by population are Olomouc with 100,663 inhabitants, Prostějov with a population of 43,651 , Přerov with 42,871 inhabitants and Šmperk with a population of 25,836 (CZSO, 2020).

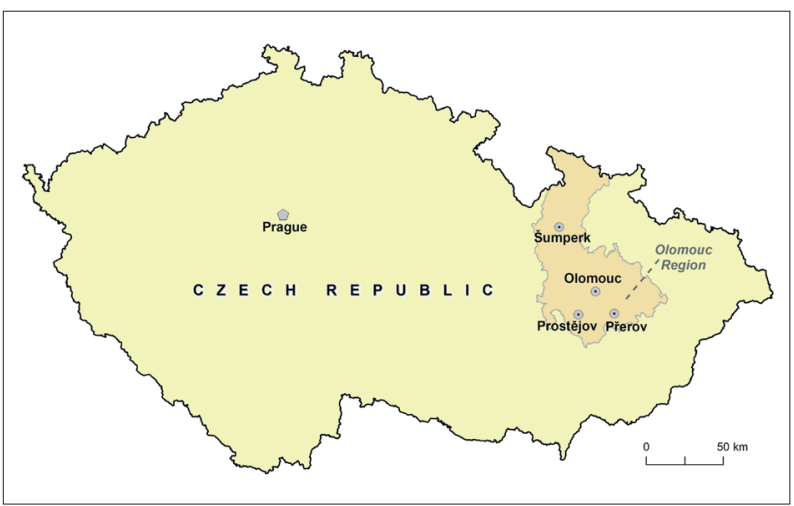

Fig. 1: Location of the Olomouc Region and cities under study. Source: ArcČR, 2016; authors' processing
All four cities are administrative centres of their districts (LAU1 sub-regions) and Olomouc is also the headquarters of the NUTS3 regional government. Unlike the other three cities, Přerov has a high ratio of unemployed to employed people (see e.g. Frelich, 2019). Moreover, Přerov differs in that it also has a high ratio of Roma people and several so called excluded locations (e.g. Čada et al., 2015; Topinka and Janoučková, 2009). These facts are important regarding the topic of the study, as they allow us to explore and compare the results and possible differences between Přerov and the other cities in the study.

\subsection{Research design}

The basic design for this study was survey research, hence the data source was administration of a questionnaire. A pilot survey was carried out in March, 2019, in which the main goal was to create more precise and understandable questions for all respondents. The questionnaire was implemented in several waves and the first took place in April, 2019. In the course of this wave, a face-to-face interview was carried out by thoroughly trained students, who addressed respondents in the four largest cities of the Olomouc Region - Olomouc, Prostějov, Přerov and Šumperk. Afterwards, an on-line version of the questionnaire was prepared, and consequently the survey underwent the CAWI (Computer Assisted Web Interviewing) method until January 2020. Moreover, this version of the questionnaire was disseminated by the criminality prevention managers of the Olomouc region and the affected cities. The information about the ongoing survey was shared on the cities' websites and in the local and nationwide public and private media. The last wave of the survey was conducted in January 2020, in order to make the sample representative (in relation to the respondents' gender, age and place of residence).

As stated, a combined method was used when collecting the questionnaire responses, and the choice of face-to-face interviews can be considered as a mix of random and quota selections. In the case of the online version, self-selection was evident. Despite the fact that this is not a probability selection, the authors consider it as representative because of the partial probability quota choice of the respondents. In total 3,205 questionnaires were collected in the four analysed cities (811 in Olomouc, 508 in Prostějov, 1,410 in Přerov, and 476 in Sumperk). The limit in the minimum number of respondents, as given by the Raosoft company online calculator ${ }^{1}$ for the selection set computation, was exceeded in all cases. If there was no information about a respondent's gender, age or place of residence, the questionnaire was discarded from the analytical part of the sample. The largest number of these discarded questionnaires was in Přerov (23.5\%), the lowest number was in Sumperk (13.9\%). The final structure of the sample is represented in Table 1.

It can be said that the respondents' structure by gender, age and place of residence (evaluated at the level of the city parts) usually corresponded to each particular city's population structure; see the assessment of the $\chi^{2}$ test on the level of significance $\alpha=0.05$ (Tab. 1). Nevertheless, in order to obtain more precise results, it was agreed to attach weights to the particular respondent groups according to their basic demographic characteristics (weights ${ }^{2}$ were constructed on

\footnotetext{
${ }^{1}$ http://www.raosoft.com/samplesize.html

2 The variables of gender and respondent's age were considered for weight determination. The respondent's place of residence was not included in the computation because of the absence of data (it was not possible to divide some of the less populated settlement units by gender). Moreover, it is apparent from the $\chi^{2}$ test results that the respondents' structure by their place of residence in all cases corresponded to the adult population structure of the particular cities.
} 


\begin{tabular}{|c|c|c|c|c|c|c|c|c|c|c|c|c|c|}
\hline \multirow{3}{*}{ Age group } & & \multicolumn{3}{|c|}{$\begin{array}{c}\text { Olomouc } \\
(84,097 \text { inhabitants })\end{array}$} & \multicolumn{3}{|c|}{$\begin{array}{c}\text { Prostějov } \\
(37,067 \text { inhabitants })\end{array}$} & \multicolumn{3}{|c|}{$\begin{array}{c}\text { Přerov } \\
(36,827 \text { inhabitants })\end{array}$} & \multicolumn{3}{|c|}{$\begin{array}{c}\text { Šumperk } \\
(22,009 \text { inhabitants })\end{array}$} \\
\hline & & \multirow{2}{*}{ Total } & \multicolumn{2}{|c|}{ Out of } & \multirow{2}{*}{ Total } & \multicolumn{2}{|c|}{ Out of } & \multirow{2}{*}{ Total } & \multicolumn{2}{|c|}{ Out of } & \multirow{2}{*}{ Total } & \multicolumn{2}{|c|}{ Out of } \\
\hline & & & $\mathrm{M}$ & $\mathrm{F}$ & & M & $\mathrm{F}$ & & M & $\mathrm{F}$ & & M & $\mathrm{F}$ \\
\hline $15-19$ & & 49 & 27 & 22 & 25 & 15 & 10 & 79 & 43 & 36 & 38 & 20 & 18 \\
\hline $20-29$ & & 223 & 112 & 111 & 78 & 33 & 45 & 281 & 134 & 147 & 58 & 30 & 28 \\
\hline 30-39 & & 95 & 50 & 45 & 71 & 32 & 39 & 242 & 123 & 119 & 58 & 24 & 34 \\
\hline $40-49$ & & 82 & 42 & 40 & 73 & 34 & 39 & 172 & 92 & 80 & 60 & 28 & 32 \\
\hline 50-64 & & 92 & 43 & 49 & 87 & 41 & 46 & 192 & 98 & 94 & 83 & 41 & 42 \\
\hline 65 and more & & 96 & 36 & 60 & 99 & 38 & 61 & 112 & 48 & 64 & 113 & 48 & 65 \\
\hline total & & 637 & 310 & 327 & 433 & 193 & 240 & 1,078 & 538 & 540 & 410 & 191 & 219 \\
\hline p-value & gender, age & & 0.000 & & & 0.457 & & & 0.000 & & & 0.302 & \\
\hline$\left(\chi^{2}\right.$ test $)$ & city part & & 1.000 & & & 0.700 & & & 1.000 & & & 0.898 & \\
\hline
\end{tabular}

Tab. 1: Sample structure by gender and age supplemented with $\chi^{2}$ test results assessing the potential difference of the sample structure and population for the variables of gender, age and place of residence

Notes: The bold font represents p-values that are lower than the chosen level of significance $\alpha=0.05$, which means that the sample structure statistically significantly differs from the population structure. The numbers in brackets below the names of the cities represent the number of inhabitants aged 15 or more as of 31 December 2019.

Sources: CZSO (2020); authors' processing

the basis of the ratio between the representation of the stated population group in the sample and in the whole population). The sum of the weights assigned to all respondents was in accordance with the total number of respondents (see Tab. 1), i.e. only for those not discarded for the incompleteness of their answers.

The questionnaire included closed and semi-closed questions, but the most important part was the map work. In this part there were two questions in which each respondent plotted where she/he did not feel safe at the moment, and where she/he did not feel safe 10 years ago. Beside the map plotting, the respondent had the task of specifying the reason for her/his choices, as well as quantifying the level of fear on a 3-point scale, and deciding in which part of the day she/ he feels the fear (day, night, throughout the whole day). As it was important to keep working with the reasons for their plotting, several categories were created with respect to the use of the quantitative methodological approach. The reasons were subsequently sorted into respective categories.

As with other studies working with the mental maps of respondents (e.g. Curtis, 2012; Doran and Burgess, 2011; Pánek et al., 2018; Šerý and Šimáček, 2012), the subsequent processing of the respondents' map plotting was carried out in the GIS environment. The level of perceived fear declared by the respondent was assigned to the final outputs in the form of a weight dedicated to each of the marked places of fear. The final areas of perceived fear - or 'fearscapes' as they are called by Tulumello (2015) - were defined by the sequential overlapping of the particular respondents' outlines and their sum (i.e. the sum of their weights) in a vertical progression. In addition, final areas were distinguished by the extent of the fear and the time (from both linear and cyclical perspectives), when the location is perceived by the respondents to be problematic. In order to have a clear arrangement of the output visualisation, the final maps contain only those locations which were marked by at least $3 \%$ of the respondents, but $100 \%$ is not equal to all the respondents who took part in the survey. It only included those respondents whose answer to the question of whether or not they felt fear of crime in their city of residence was not an absolute no (i.e. the possible answers were; definitely, more likely, probably not). In the retrospective investigation into places that produced fear of crime 10 years ago, respondents who had not lived in the city for at least the last 10 years $^{3}$ were not included in the analysis. For the representation of a perceived fear level, a Fear of Crime index (FoC) was used in the map outputs. This index represents not only the share of respondents who marked the location, but also takes into consideration the perceived fear level:

$$
\text { FoC } \text { index }=\frac{\text { respondent weight } \times \text { perceived fear level }}{\text { number of respondents } \times 3} \times 100(\%)
$$

The FoC value of $100 \%$ means that all respondents who should have marked the locations of perceived fear in their particular city did so, and they mentioned the highest level of fear of crime, i.e. 3 .

\subsection{Methodological limitations}

The authors of this study are well aware of some of the limitations. First, it is necessary to mention an approach to data collection using the combined techniques of on-line and face-to-face questionnaires. The primary technique of data collection was on-line questioning which, however, had to be supplemented by face-to-face questioning due to the very limited use of the Internet by older people ${ }^{4}$. Verification of compliance in the results achieved by these different data collection techniques (while maintaining the same questionnaire) was not possible due to the different age structures of respondents in the on-line and face-to-face surveys.

\footnotetext{
${ }^{3}$ Also, respondents aged 15-19 were not included in this case, as their ability to respond to questions about the situation 10 years ago is very limited, to say the least.

${ }^{4}$ The percentage of people aged 65 and over who did not use the Internet was 67\% in 2014 (Hedvičáková, Svobodová, 2017).
} 
The use of the level of perceived fear as a weight in the calculation of the $\mathrm{FoC}$ index also might appear to be a potential methodological shortcoming. Although it was possible to proceed with the transformation and adjustment, the authors, following the example of some other indices used (e.g. education index), decided to keep the ordinal character of the variable as a weight, in order to highlight areas with the highest levels of perceived fear of crime. It is obvious that in light of the above information, the interpretation of the FoC index results must be carried out carefully and in accordance with the chosen calculation.

There is also the questionable accuracy of the respondents' plotted places of fear. Although the plotting map background was intentionally presented in the form of an uncluttered topographical map, many of the respondents had difficulty with orientation in their own city, and this makes it harder to find the perceived places of fear. Another limitation was the absence of similar research carried out in the studied cities since that would have made it possible to see the changes in the meaning of places from a long-term perspective. Therefore, it was necessary to ask the respondents about their perceived places of fear 10 years ago. Naturally, this question was sometimes seen as difficult one, requiring respondents to recall their feelings of fear in their cities a decade ago. Hence, it is probable that some of the respondents were not able to recall all the problematic places or the reasons why they were problematic. Verification of this thesis is possible only through long-term research, requiring similar surveys to be conducted.

\section{Results and discussion}

First it has to be said that not all respondents reported a fear of crime in their city. In this matter, each of the examined cities differed from the others. While almost $19 \%$ of the respondents in Olomouc and Šumperk stated they had no fear of crime, that proportion was $14 \%$ in Prostějov and $4 \%$ in Přerov. Regarding this perception, more men than women chose this option in all the cities. As regards age, respondents aged 65 or more were undoubtedly the largest group (the ratio of this age group's respondents who did not feel the fear of crime was almost double in all the cities, in comparison with the figures stated above). That result contradicts several (mostly older) case studies which, in contrast, highlighted a positive correlation between age and the intensity of the perceived fear of crime (Box et al., 1988; Clememte and Kleiman, 1976). On the other hand, there are more studies whose results demonstrate that this relationship is not clearly relevant (Chadee and Ditton, 2003; Sakip et al., 2018), as with this study. Furthermore, another relevant explanation can be found in the Jíchová and Temelová (2012) study, which refers to some inhabitants (primarily the older ones) who are not able to assess the fear of crime completely, owing to their limited outdoor activities. As mentioned in the previous Section, all the subsequent analyses were carried out using a case unit composed of respondents who felt at least some fear of crime in their city, i.e. those that could make an outline of the places of fear on the enclosed maps.

\subsection{The temporality of the topophobic meaning of places from a long-term perspective}

Based on the data analysis, there are places which demonstrated stability, as well as those with certain changes in their meaning over the course of time. Focusing on the linear perception of time analysis, it is possible to discover a deterioration in the situation throughout all the explored cities when compared with 10 years ago (see Fig. 2). The situation is expressed not only with the frequency of the respondents' outlines (the colour scale), but also often with an increased level of perceived fear (the purple line delimiting the areas with the $\mathrm{FoC}$ index value $>10 \%$ ).

From the spatial point of view, the defined locations in Olomouc in both time periods were seen to be mostly stable, but in relation to time, a change in the level of perceived fear was observed, i.e. the situation had worsened over time. While the FoC index had a maximum value of $8.6 \%$ ten years ago, recently it reached $17.6 \%$, and the locations with an index over $10 \%$ covered an area of approximately 3.7 ha. As for the most critically perceived locations, the first was the main train station, including the space in front of the building. The city's parks were also featured (mostly Smetanovy sady).

In the other cities there was a clear change in the meaning of places, both in space and time. For example, in Prostějov more places of fear were currently identified than the situation 10 years ago. For the most distinct changes, almost the whole wider city centre appeared to be a place of fear. Another new situation was the spread of the area of fear from the city centre to the east, towards the main train station. There was also a slight deterioration in the situation in Kolářovy sady, including the identification of a new place of fear in the surroundings of the Městský Pond (south-west of the centre). Another new place of fear was the Spojencu Square (north-east of the centre). In the city district of Vrahovice fear of crime was felt in the surroundings of the lodging house (north-east of the main train station). On the other hand, there is no longer a place of fear in the area on the map's western edge (U svaté Anny), where there used to be a Romany colony, and there was also a slight improvement in the situation in Husovo Square (to the east of the centre). As for the detected $\mathrm{FoC}$ index values, at present only a subtle increase of approximately half a percentage point to $14.1 \%$ was observed at the most critical location (i.e. the main train station). Regardless, the extension of the area of fear is obvious. In contrast, in another location largely perceived as a place of fear (Husovo Square), there was a modest decrease in the $\mathrm{FoC}$ index, as well as a reduction in the size of the area of fear, especially in its western section.

In Přerov, the area of fear is much larger than it was 10 years ago (from 84.8 ha ten years ago to 345.6 ha today). Moreover, the extension of the fear of crime area was, on the basis of the respondents' opinions, identified as the largest in all the examined cities. Apart from the areal spread along almost the whole area of the compact city south of the river, a new place of fear was defined on the north side of the Bečva River: the Velká Dlážka housing estate. There is also an apparent extension of the area where respondents declared a higher level of fear. The core of the most critical location ten years ago was the immediate surroundings of the main train station (especially Husova and Škodova Streets north of the station). Presently, beside this site, a bus terminal (situated south-east of the main train station) has become part of the core. While the maximum FoC index value was $25.8 \%$ ten years ago and the area of FoC index $>10 \%$ was an estimated 16.1 ha at that time, currently the maximum of the FoC is $37.9 \%$ and the area's FoC $>10 \%$ is approximately 41.3 ha (2.4 ha with the FoC > 30\%).

Certain changes can also be observed in Šumperk. Over time there has been an increase in the number of identified places of fear and a rise in the local level of perceived fear. 
Compared with the situation 10 years ago, part of the city centre was newly identified as a place of fear (mostly the historical centre's north-east part), and a new place of fear was found in the Dolní Temenice housing estate district (north-west of the centre). Regarding the perceived fear level, the maximum FoC index value 10 years ago was $9.1 \%$, while currently it is more than double at $18.8 \%$. The most critical place in this respect is the southern part of the city park (Sady 1. máje), situated north of the main traffic terminal, including the train and bus stations. The area where the $\mathrm{FoC}>10 \%$ is approximately 2.1 ha.

\subsection{The temporality of the topophobic meaning of places based on everyday experience}

With respect to the respondents' outlines, they had the opportunity to express whether they felt fear in a place during the day, during the night or throughout the whole day. Although there were three possible choices, the data definitely showed that the locations perceived as places of fear only during the day, accounted for only a marginal percentage of the outlines. Moreover, in none of the studied cities was there a location where

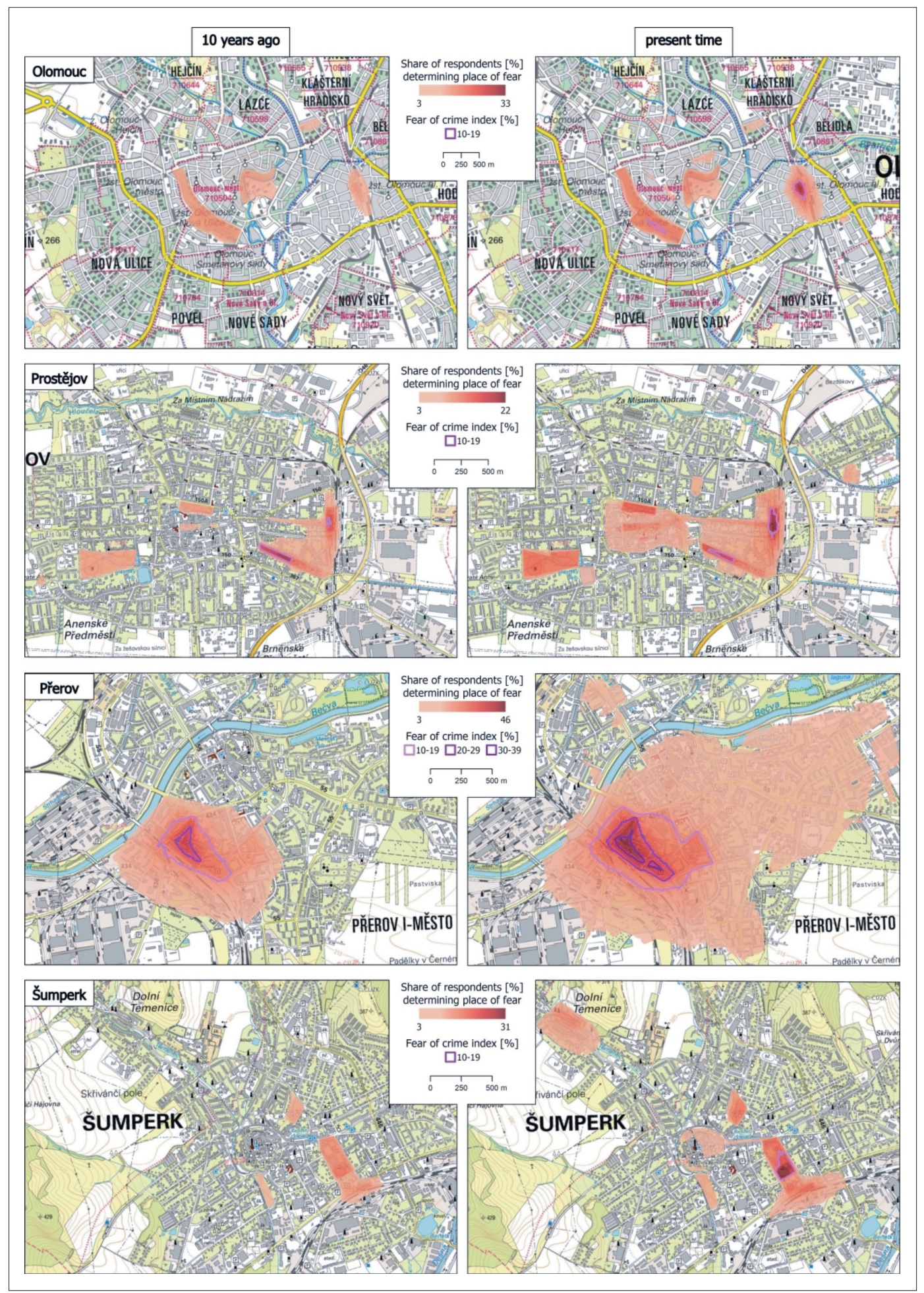

Fig. 2: Topophobia based on the experience of fear of crime-long-term differences

Sources: authors' survey and processing; background map (c) ČUZK, 2020 
at least three percent of the respondents agreed in their outlines. For this reason, there are no maps of places of fear for the day in Figure 3.

Comparing the occurrence of places of fear in the studied cities, a few similarities can be observed in Olomouc, Prostějov and Šumperk with respect to the daily hours. A visible increase in the outline frequency was detected in several clearly defined locations during the night in all these cities. Those locations were mainly parks and green squares, and in Prostějov and Sumperk this included the spaces in front of the train stations (the space in front of the train station in Olomouc was also perceived as one of the most critical places after dark, although a little less than over the whole day). As for the perceived fear level expressed by the FoC index, each of the three cities had different results when comparing the night hours with a whole day.

An FoC $>10 \%$ during the night was only detected in Prostějov (10.1\% at the main train station) and additionally, only in a restricted area of about two dozen square metres. In Olomouc, an $\mathrm{FoC}>10 \%$ was not recorded during the night hours, but it did emerge in the results for the whole

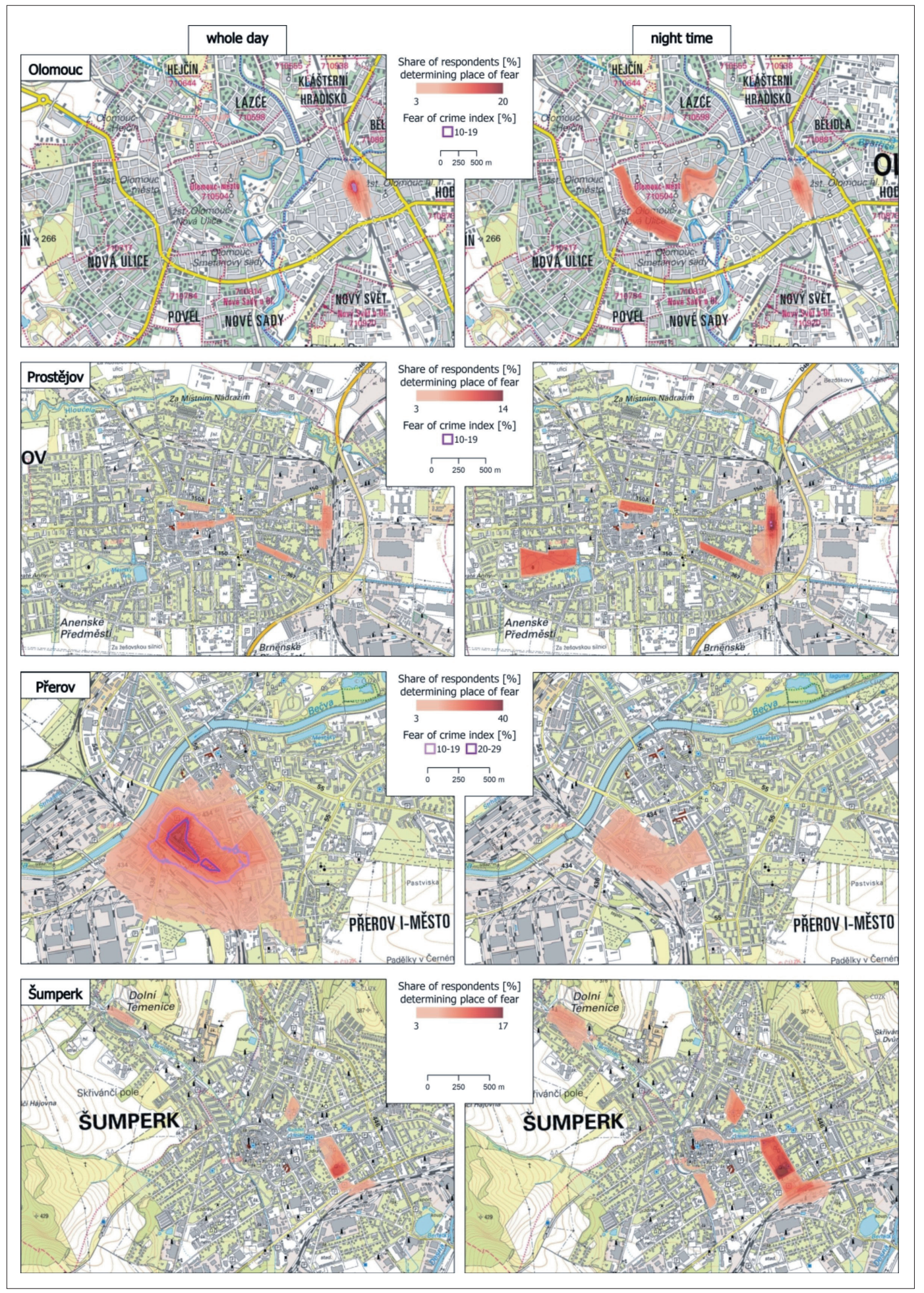

Fig. 3: Topophobia based on the experience of fear of crime-differences within the day Sources: authors' survey and processing; background map (c) CUUZK, 2020 
day (11.1\% over an area of 0.2 ha by the main train station). Unlike Prostějov and Olomouc, in Sumperk an $\mathrm{FoC}>10 \%$ was not observed anywhere over any period of the day.

In striking contrast, in the fourth studied city, Přerov, the findings substantially differed from those in the other three. Not only was there no increase in the places of fear during the night, but the highest relative frequency of the outlines was at least double the value found in the other cities. Furthermore, Přerov had the highest level of perceived fear of all the studied cities $(29.1 \%$, not far north of the train station). The extension of the $\mathrm{FoC}>10 \%$ area accounted for about 25.8 ha (4.6 ha with the FoC $>20 \%$ ).

There are also similarities between our research and other studies from post-socialist European cities. Pődör et al. (2016), in their research on the city of Nagykanizsa in Hungary, also identified the city centre as an area of fear of crime. A study from Lublin in Poland (Pantyley et. al, 2017) presents similar types of places with similar fears of crime to the cities included in our research. Moreover, the Lublin study shows differences between the night (bus and train stations, city parks and cycling paths along the river were mentioned most) and the day (areas surrounding blocks of flats, city gates, vicinities of social buildings were often mentioned).

\subsection{Types of places of fear of crime and their temporality}

Based on the temporality of the topophobic meanings attributed to places, we identified four types of places. These specific urban places are likely to represent various environments in particular cities. Concerning the spatiality of the first type of place, where the topophobic meaning is changing over linear and cyclical time, our findings from Olomouc and Šumperk suggest that city centres are examples of such a type. Similar findings concerning city centres are also described in the study by Pánek et al. (2018). As for the second type of places, where topophobic meaning only changes over linear time and is stable over cyclical time, some residential neighbourhoods in Prostějov and Šumperk can be seen as examples. Municipal parks can be recognised as typical representatives of the third type of place, where topophobic meaning only changes over cyclical time and is stable over linear time. This corresponds with the Jim and Chen (2006) and Sreetheran and Bosch (2014) research results, which deal with the perception of municipal parks and public green areas as potential places of fear of crime. Nevertheless, the time factor has proved to be an important element here: while from the linear time point of view there is stability in the meaning of place, the view of daily periods can cause the perception of the parks to be more reflexive, since parks gain their problematic labels mostly after dark (see the results from Olomouc). All four cities under study have a historical centre surrounded by residential and industrial districts. Only in Olomouc, however, is the historical centre is surrounded by municipal parks. Therefore, it can be difficult for the inhabitants of Olomouc to avoid them while walking to and from the city centre. For this reason, the parks can be perceived as dangerous places along the important routes between the city centre and people's homes. Although it is possible to avoid the parks while going to and from the city centres in Prostějov and Šumperk, even there the parks represent significant places of fear. Still, when compared to the other cities, the parks in Prrerov (except for the public green place in the Svobody Square - east of the main train station) do not play an important role in forming places where there is a fear of crime.
The typical representatives of the fourth type of identified places are the train stations, where a strong topophobic meaning is stable over time. This agrees with the results of the work by Cozens et al. (2003), which characterised train stations and their closest surroundings as problematic places, stable in time. In contrast to the study of Cozens et al., however, we do not see the main reason being the poor physical appearance of the environment, but primarily it is the people in the train stations' surroundings. The case of Přerov is the clearest of all, since the time aspect regarding the image of the train station's location is insignificant for the city's inhabitants. Based on their own experiences, the place has a strong negative meaning, and it is mostly connected to unpleasant interactions among diverse social groups.

\subsection{Reasons for the dependence of perceived fear on time}

The specific reasons why the respondents felt a fear of crime were classified into 15 categories; the last category included all the previously unclassified ideas. While creating the categories, the authors took into account knowledge from other research (specific population groups - e.g. drunk people, the Roma; the physical environment and its characteristics e.g. parks, insufficient lighting) and the clearly repeated statements of the respondents (e.g. re: socially unadaptable people). Most categories were based on socially related factors. Here, we have evidence in support of the argument made by Sandercock (2005), who states that the expressions of fear of crime are fear of others. Similar findings were also defined in the research on the Kings Cross locality in Sydney, where 16 environmental cues which mostly trigger fear of crime were defined (Doran and Burgess, 2011, p. 221). Intoxicated people (with drug- and alcohol-related issues) are the most serious cause of an increase in fear of crime. These findings are in line with Pődör et al. (2016), who found that the frequent movement of Roma minority groups generates a strong fear of crime among the inhabitants of Nagykanizsa in Hungary.

Since the representation of some categories in the particular cities was relatively few, in comparison with the main reasons for the fear of crime, only the most common reasons are shown in the graphic representation. For the periods 10 years ago and now, the top five most frequently stated reasons were chosen. As they were not the same (neither in relation to cities nor to periods of time), nine are presented in Figure 4.

The structure of the reasons also varied in time and space. Comparing the current reasons for the fear of crime and those of 10 years ago, it is obvious that most were mentioned less in the past (Fig. 4), although there are a few exceptions: the greatest difference in the percentages points in the direction of 'situation improvement' was seen in Šumperk (reason: socially unadaptable people) and in Prostějov (reason: the Roma people). The only reason respondents highlighted more 10 years ago in some of the cities, was the fear of being attacked (in Olomouc and Prostějov). The contrast, however, was only minimal. In addition, in Olomouc both noise and poor lighting were mentioned 10 years ago, therefore certain improvement can be inferred in these factors. A deterioration can be seen based on many of the reasons given for fear of crime, however, because most were mentioned more in the present day. The greatest overall increase in percentage points was in the following reasons: drug addicts, homeless and drunk people. Even so, there were considerable differences among the particular cities. A comparison of the relative frequency (i.e., how often 


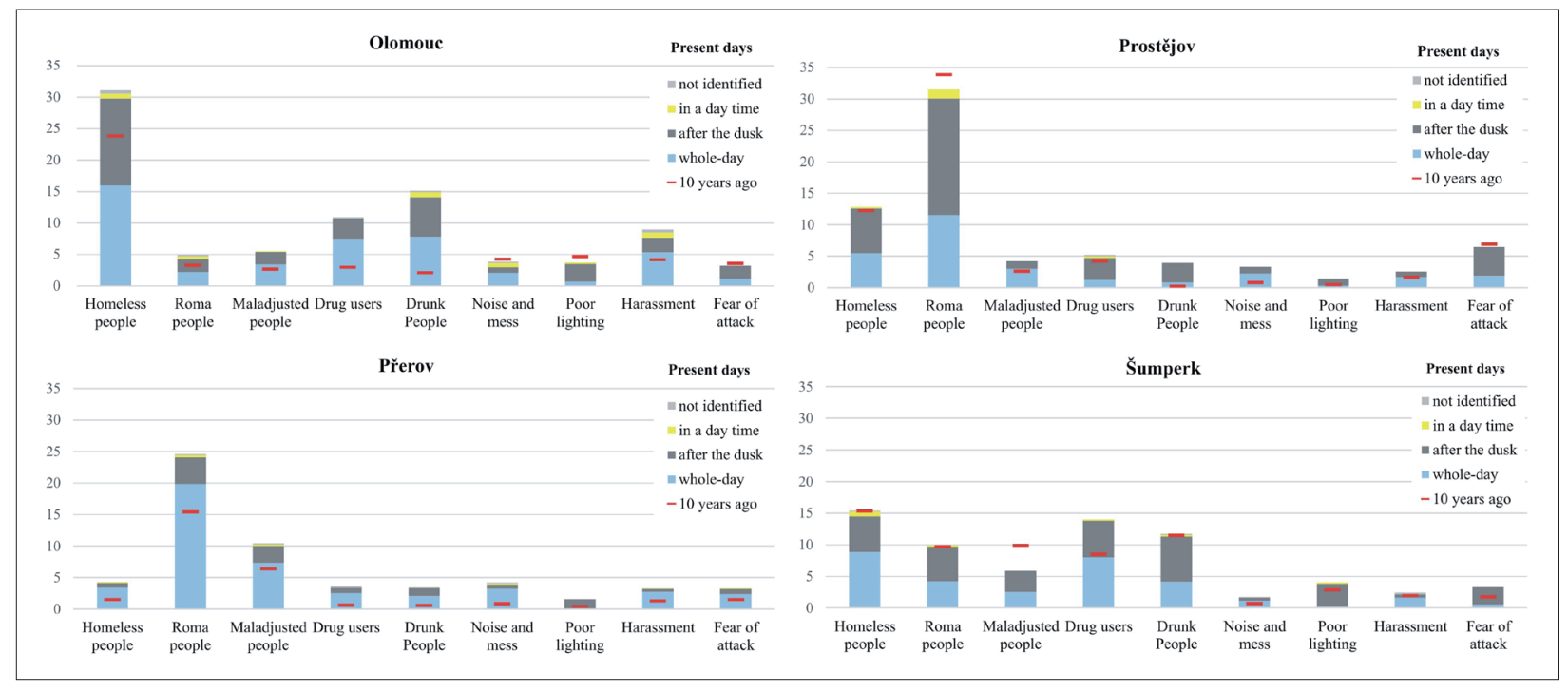

Fig. 4: The most common reasons for the outlines (the y axis represents the percentage of the outlines with the given reason with respect to the total number of outlines in the city). Sources: authors' survey and processing

a particular reason was mentioned compared to the others) also leads to some important findings. In comparison with the other reasons, homeless people and the Roma people were mentioned more 10 years ago, but drunk people and drug users are remembered presently instead.

Reasons for the perceived fear of crime also vary with respect to the time of day. Except for the highly specific case of Přerov, all other cities demonstrated two separate groups of respondents in most of the reasons: the first group felt fear throughout the whole day, while the other group only felt it at night (apart from the reasons connected to poor lighting, for example, which is a typical side-effect of the dark hours). As the results clearly show, the least amount of fear perceived by the respondents was in the places marked 'only during the day'. The only exception in this matter is the poor lighting in Šmperk, where the 'whole-day' option had a 0.01 smaller percentage point than the variant 'only during the day'. This variant was found in more than $1 \%$ of the outlines in Prostějov, with the reason given as the Roma people (Fig. 4). In all four cities the differences between the 'wholeday'and 'only during the night' reasons were mainly related to the noise and harassment (these reasons mostly occurred throughout the whole day), poor lighting (the reason mostly occurred, logically, at night) and the fear of being attacked (the reason also occurred at night except for the very specific case of Přerov, where this reason occurred more throughout the whole day). The fact that the respondents from Přerov experienced fear of crime more often throughout the whole day rather than just at night, reflects the strength of the meaning of the core area of fear in Přerov.

\section{Conclusions}

For the first and second research questions, based on the findings it is possible to confirm the changes as well as the stability of topophobia in the identified places in the context of fear of crime, both in the long-term time perspective and in everyday repeated experiences. As shown by the results, in the case of parks, a change in a place's topophobic meaning dependent on time (especially from a cyclical time perspective) can be observed. In contrast, when speaking about train stations and their surroundings, a stable negative meaning in linear time as well as in cyclical time can be observed. These stable or changing topophobic meanings did not emerge from nowhere. Rather, they can be interpreted as part of the becoming of individual consciousness (Pred, 1984). This means the topophobic meanings of places are interwoven with the biographical formation and becoming of place. Our results also suggest the use of both the life path and the daily path of residents in order to attribute topophobia to specific places. Connecting the paths of two or more people fuels collectively shared topophobic meanings of places that are temporally specific, place by place. Regarding the third research question; in most cases the respondents determined that the reasons for fear were primarily particular social groups, such as homeless people, ethnic groups (the Roma) and those under the influence of alcohol and narcotics (drunk people and drug users).

In the final analysis, the results of our research suggest that in urban places the temporality of topophobic meanings, drawn from the experience of fear of crime, can vary considerably. The content of places means many things to different residents, and in general they are capable of interpreting, praising and evaluating the places in which they live (Amedeo, 1993), and temporality is applied here in an essential way. As such, these findings support the conceptualisation of place as a process, or in other words as a constantly becoming human entity (Pred, 1984). In this context, we can distinguish between four types of topophobic places that have been identified. First, the places with topophobic meaning that changes over linear as well as cyclical time. Second, the places with topophobic meaning that changes only over linear time. Third, the places whose topophobic meaning changes only over cyclical time. The first three types of place support the point made by Golledge and Stimson (1997, p. 393), who state that "perception or cognition of the place, its symbolism, its meaning, its cultural significance, and even its boundaries, may change". Fourth, we managed to explore and identify the places with a strong topophobic meaning that is stable in the longterm as well as over a single day. The residents similarly operated and interpreted the information sensed from these places and subsequently ascribed congruent meaning to the information, regardless of the time dimension.

The results suggest that both concepts of time can be employed in the fixation of topophobic meanings derived from the experience of fear of crime in four different ways. 
In general, these conclusions imply the necessity for an individual approach to urban places, when policy makers attempt to understand specific places in their city. This is understood to be a crucial step before planning a new use for an area or using it for its original purpose and, more widely, for the process of urban planning. As Ceccato (2020c, p. 412) declares, urban planners and other municipality workers responsible for urban development would like to work more with safety issues in mind when planning. This effort can lead to a reduction in opportunities for crime and also to a reduction in or even an elimination of topophobic places.

This paper has particularly highlighted the stability and changes in topophobic meanings related to specific urban places, depending on the aspect of time. Simultaneously, it revealed other research problems whose examination could contribute to deeper knowledge. Follow-up research should elaborate on the influence of the socio-demographic characteristics of residents, regarding how intensively and why fear of crime is attributed to specific urban places. Similarly, the socio-demographic profile of the inhabitants should be considered in the research into the spatial and temporal dimensions of fear of crime.

\section{Acknowledgement}

The paper is an output from the project: "Innovation of crime prevention in cities of Olomouc region based on mapping of localities of crime fear" (TL02000556), funded by the Technology Agency of the Czech Republic.

\section{References:}

ADU-MIREKU, S. (2002): Fear of crime among residents of three communities in Accra, Ghana. International Journal of Comparative Sociology, 43(2): 153-168.

AMEDEO, D. (1993): Emotions in person-environmentbehavior episodes. In: Gärling, T., Golledge, R. [eds.]: Behavior and Environment (pp. 83-116). Amsterdam, Elsevier Science Publishers.

ANDREESCU, V. (2013): Fear of Violent Victimization among the Foreign-Born. Journal of Identity and Migration Studies, 7(1): 69-94.

ANDRESEN, M. A., MALLESON, N. (2013): Crime seasonality and its variations across space. Applied Geography, 43: 25-35.

ArcČR (2016): Digital Geographic Database. Czech Statistical Office and Czech Office for Surveying, Mapping and Cadastre.

ATKINS, S., HUSAIN, S., STOREY, A. (1991): The influence of street lighting on crime and fear of crime. London, Home Office.

BANNISTER, J., FYFE, N. (2001): Introduction: Fear and the City. Urban Studies, 38(5-6): 807-813.

BOX, S., HALE, C., ANDREWS, G. (1988): Explaining fear of crime. The British Journal of Criminology, 28(3): 340-356.

BRENNAN-HORLEY, C. (2010): Mental mapping the 'creative city'. Journal of Maps, 6(1): 250-259.

BRISUDOVÁ, L., ŠIMÁČEK, P., ŠERÝ, M. (2020): Mapping topo-ambivalent places for the purposes of strategic planning of urban space. The case of Šternberk, the Czech Republic. Journal of Maps, 16(1): 203-209. Doi: 10.1080/17445647.2020.1844087
CECCATO, V. (2020a): The circumstances of crime and fear in public places. In: Ceccato, V., Nalla, M. [eds.]: Crime and Fear in Public Places: Towards Safe, Inclusive and Sustainable Cities (pp. 16-37). New York, Routledge.

CECCATO (2020b): The architecture of crime and fear of crime. In: Ceccato, V., Nalla, M. [eds.]: Crime and Fear in Public Places: Towards Safe, Inclusive and Sustainable Cities (pp. 38-71). New York, Routledge.

CECCATO (2020c): Safety in the making: An assessment of urban planners' practices in municipalities in Sweden. In: Ceccato, V., Nalla, M. [eds.]: Crime and Fear in Public Places: Towards Safe, Inclusive and Sustainable Cities (pp. 401-416). New York, Routledge.

CECCATO, V., LUKYTE, N. (2011): Safety and sustainability in a city in transition: The case of Vilnius, Lithuania. Cities, 28(1): 83-94.

CHADEE, D., DITTON, J. (2003): Are older people most afraid of crime? Revisiting Ferraro and LaGrange in Trinidad. British Journal of Criminology, 43(2): 417-433.

CLEMEMTE, F., KLEIMAN, M. B. (1976): Fear of crime among the aged. The Gerontologist, 16(3): 207-210.

COZENS, P., NEALE, R., WHITAKER, J., HILLIER, D (2003): Managing crime and the fear of crime at railway stations-a case study in South Wales (UK). International Journal of Transport Management, 1(3): 121-132.

COZENS, P., LOVE, T. (2015): A review and current status of crime prevention through environmental design (CPTED). Journal of Planning Literature, 30(4): 393-412.

CRANG, M. (2011): Time. In: Agnew, J., Livingstone, D. [eds.]: The Sage Handbook of Geographical Knowledge (pp. 331-343). London, Sage.

CRESSWELL, T. (2008): Place: encountering geography as Philosophy. Geography, 93: 132-139.

CURTIS, J. (2012): Integrating Sketch Maps with GIS to Explore Fear of Crime in the Urban Environment: A Review of the Past and Prospects for the Future. Cartography and Geographic Information Science, 39(4): 175-186.

CZSO (2020): Public Database - Customized Selection Population by 31.12.2019 [online]. Website of Czech Statistical Office [cit. 2020-10-26]. Available at: https://www.czso.cz/documents/11276/25976488/ OLK VEK obyv obce 19.xlsx/f3ca92c3-c535-40a8-bfc374bde2582265? version $=1.1$

ČADA, K., BÜCHLEROVÁ, D., KORECKÁ, Z., SAMEC, T., OUŘEDNÍČEK, M., KOPECKÁ, Z. (2015): Analysis of Socially Excluded Localities in the Czech Republic [online]. [cit. 2020-02-22]. GAC spol. s. r. o. Available at: https://www.esfcr.cz/documents/21802/791224/ Analysis + of +Socially+Excluded+Localities +in+the+CZ . pdf/681c6783-18ca-4f45-a3ea-ac97b5ce11a4

ČÚZK (2020): Basic map of the Czech Republic. Czech Office for Surveying, Mapping and Cadastre.

DANĚK, P. (2013): Geografické myšlení: úvod do teoretických přístupů. Brno, Masarykova universita.

DORAN, B. J., BURGESS M. B. (2011): Putting Fear of Crime on the Map: Investigating Perceptions of Crime Using Geographic Information Systems. New York, Springer Science and Business Media. 
ELLEGÅRD, K. (2019): Thinking time geography: Concepts, methods and applications. Oxford and New York, Routledge.

FRANTÁL, B., BEVK, T., VAN VEELEN, B., HĂRMĂNESCU, M., BENEDIKTSSON, K. (2017): The importance of on-site evaluation for placing renewable energy in the landscape: A case study of the Búrfell wind farm (Iceland). Moravian Geographical Reports, 25(4): 234-247.

FRELICH， J. (2019): Nezaměstnanost v Olomouckém kraji k 31. 3. 2019. Website of Czech Statistical Office [online]. [cit. 2020-02-20]. Available at: https://www.czso.cz/documents/11276/113164151/ NEZ2019_03.pdf/42d53102-55fe-4e44-b3 78 5 daaaca0a9ae?version $=1.1$

GABRIEL, U., GREVE, W. (2003): The psychology of fear of crime. Conceptual and methodological perspectives. British Journal of Criminology, 43(3): 600-614.

GHIOCA, S. (2014): The cognitive map's role in urban planning and landscaping: application to Braila City, Romania. Cinq Continents, 4(10): 137-157.

GLAS, I., ENGBERSEN, G., SNEL, E. (2019): The street level and beyond: The impact of ethnic diversity on neighborhood cohesion and fear of crime among Dutch natives and nonnatives. Journal of Urban Affairs, 41(6): 737-755.

GOLLEDGE, R. G., STIMSON, R. J. (1997): Spatial Behavior: A Geographic Perspective. New York, Guilford Press.

GOULD, P., WHITE, R. (2005): Mental Maps. London, Routledge.

GRAY, E., JACKSON, J., FARRALL, S. (2011): Feelings and functions in the fear of crime: Applying a new approach to victimisation insecurity. The British Journal of Criminology, 51(1): 75-94.

GROHE, B., DEVALVE, M., QUINN, E. (2012): Is perception reality? The comparison of citizens' levels of fear of crime versus perception of crime problems in communities. Crime Prevention and Community Safety, 14: 196-211.

HALE, C. (1996): Fear of crime: A review of the literature. International review of Victimology, 4(2): 79-150.

HANSLMAIER, M. (2013): Crime, fear and subjective wellbeing: How victimization and street crime affect fear and life satisfaction. European Journal of Criminology, 10(5): 515-533.

HÄGERSTRAND, T. (1983): In search for the sources of concepts. In: A. Buttimer [ed.]: The Practice of Geography (pp. 238-256). Harlow, Longman Higher Education.

HEDVIČÁKOVÁ, M., SVOBODOVÁ, L. (2017): Internet Use by Elderly People in the Czech Republic. In: Kar, A. et al. [eds.]: Digital Nations - Smart Cities, Innovation, and Sustainability (pp. 514-524). Cham, Springer.

INSTITUTE FOR ECONOMICS and PEACE (2020): Global Peace Index, 2020: Measuring Peace in a Complex World Website of Institute for Economics and Peace [online]. [cit. 2020-07-09]. Available at: http://visionofhumanity. org/app/uploads/2020/06/GPI_2020_web.pdf

IRA, V. (2001): Geografia času: prístup, základné koncepty a aplikácie. Geografický časopis, 53(3): 221-246.
IVAN, I., ORLÍKOVÁ, L., PÁNEK, J., MACKOVÁ, L. (2020): Metodika identifikace a hodnocení bezpečnostně rizikových lokalit ve městě. VŠB TUO Ostrava [online]. [cit. 2020-07-10]. Available at: https://www.mvcr.cz/ clanek/certifikovana-metodika-identifikace-a-hodnocenibezpecnostne-rizikovych-lokalit-ve-meste.aspx

JIM, C. Y., CHEN, W. Y. (2006): Perception and attitude of residents toward urban green spaces in Guangzhou (China). Environmental Management, 38(3): 338-349.

JÍCHOVÁ, J., TEMELOVÁ, J. (2012): Kriminalita a její percepce ve vnitřním městě: případová studie pražského Žižkova a Jarova. Geografie, 3(117): 329-348.

LATKIN, C., CURRY, A. (2003): Stressful Neighborhoods and Depression: A Prospective Study of the Impact of Neighborhood Disorder. Journal of Health and Social Behavior, 44: 34-44.

LLOYD, R. (1989): Cognitive maps: Encoding and Decoding Information. Annals of the Association of American Geographers, 79(1): 101-124.

LITTLE, J., PANELLI, R., KRAACK, A. (2005): Women's fear of crime: A rural perspective. Journal of Rural Studies, 21(2): 151-163.

LIU, E., FREESTONE, R. (2016): Revisiting Place and Placelessness. In: Liu, E., Freestone, R. [eds.]: Place and Placelessness Revisited (pp. 1-19). New York, Routledge.

LOPEZ, N., LUKINBEAL, C. (2010): Comparing police and residents' perceptions of crime in a Phoenix neighborhood using mental maps in GIS. Yearbook of the Association of Pacific Coast Geographers, 33-55.

MALPAS, J. (2018): Place and experience. A Philosophical Topography. London and New York, Routledge.

MARSHALL, N. (2016): Urban squares. A place for social life. In: Liu, E., Freestone, R. [eds.]: Place and Placelessness Revisited (pp. 187-203). New York, Routledge.

MASLOW, A. H. (1943): A theory of human motivation. Psychological Review, 50(4): 370-396.

MINNERY, J., LIM, B. (2005): Measuring crime prevention through environmental design. Journal of Architectural and Planning Research, 22(4): 330-341.

MULÍČEK, O., OSMAN, R., SEIDENGLANZ, D. (2015): Urban rhythms: A chronotopic approach to urban timespace. Time and Society, 24(3): 304-325.

MULÍČEK, O., OSMAN, R., SEIDENGLANZ, D. (2016): Time-space rhythms of the city - The industrial and postindustrial Brno. Environment and Planning A, 48(1): $115-131$.

OSMAN, R. (2016): Sémantická mapa: příklad Ústí nad Orlicí. Geografie, 121(3): 463-492.

PAASI, A. (2002): Place and region: regional worlds and words. Progress in Human Geography, 26(6): 802-811.

PAIN, R. (1997): 'Old age' and ageism in urban research: the case of fear of crime. International Journal of Urban and Regional Research, 21(1): 117-128.

PAIN, R. (2000): Place, social relations and the fear of crime: a review. Progress in human geography, 24(3): 365-387.

PAIN, R. (2001): Gender, race, age and fear in the city. Urban studies, 38(5-6): 899-913. 
PANTYLEY, V., RODZOŚ, J., PISKORSKI, M. (2017): Perception of urban safety: the case of Lublin, Poland. Miscellanea Geographica, 21(1): 25-34.

PÁNEK, J. (2016): From Mental Maps to GeoParticipation. The Cartographic Journal, 53(4): 300-307.

PÁNEK, J. (2018): Emotional Maps: Participatory Crowdsourcing of Citizens' Perceptions of Their Urban Environment. Cartographic Perspectives, 91: 17-29.

PÁNEK, J., PÁSZTO, V., ŠIMÁČEK, P. (2018): Spatial and Temporal Comparison of Safety Perception in Urban Spaces. Case Study of Olomouc, Opava and Jihlava. In: Ivan I., et al. [eds.]: Dynamics in GIScience (pp. 333346). Cham, Springer.

PERKINS, C. (2009): Performative and Embodied Mapping. In: Kitchin, R., Thrift, N. [eds.]: International Encyclopedia of Human Geography (pp. 126-132). Oxford, Elsevier.

PÖDÖR, A., RÉVÉSZ, A., RÁCSKAI, P., SASVÁR, Z. (2016): Measuring citizens' fear of crime using a web application: A case study. GI Forum, 2: 12-29.

PRED, A. (1984): Place as Historically Contingent Process: Structuration and the Time-Geography of Becoming Places. Annals of the Association of American Geographers, 74(2): 279-297.

RELPH, E. (1976): Place and Placelessness. London, Pion.

SALEM, G. W., LEWIS, D. A. (2016): Fear of crime: Incivility and the production of a social problem. New Jersey, Transaction Publishers.

SAKIP, S., ABDULLAH, A., SALLEH, M. (2018): Fear of crime in residential areas. Asian Journal of EnvironmentBehaviour Studies, 3(7): 81-89.

SANDERCOCK, R. J. (2005): Difference, Fear and Habitus, a Political Economy of Urban Fear. Aldershot, Ashgate.

SEMMENS, N., DILLANE, J., DITTON, J. (2002): Preliminary findings on seasonality and the fear of crime. A research note. British Journal of Criminology, 42(4): 798-806.

SHAMSUDDIN, S. B., HUSSIN, N. A. (2013): Safe city concept and crime prevention through environmental design (CPTED) for urban sustainability in Malaysian cities. American Transactions on Engineering and Applied Sciences, 2(3): 223-245.

SIWEK, T. (2011): Percepce geografického prostoru. Prague, Czech Geographical Society.

SOLYMOSI, R., BOWERS, K., FUJIYAMA, T. (2015): Mapping fear of crime as a context-dependent everyday experience that varies in space and time. Legal and Criminological Psychology, 20(2): 193-211.
SREETHERAN, M., VAN DEN BOSCH, C. C. K. (2014): A socio-ecological exploration of fear of crime in urban green spaces-A systematic review. Urban Forestry and Urban Greening, 13(1): 1-18.

STASÍKOVÁ, L. (2011): Relevantnost výskumu strachu z kriminality v urbánnej geografii. Geografický časopis, 63(4): 325-343.

STUART, J. (1969): A Citizen's View of the Impact of Crime. Crime and Delinquency, 15(3): 323-332.

SUAU, L., CONFER, J. (2006): Parks and the geography of fear. In: Peden, J. G.; Schuster, R. M., comps. [eds.]: Proceedings of the 2005 northeastern recreation research symposium (pp. 273-278). Newtown Square, PA, USDA Forest Service, Northeastern Research Station.

ŠERÝ, M., ŠIMÁČEK, P. (2012): Perception of the historical border between Moravia and Silesia by residents of the Jeseník area as a partial aspect of their regional identity. Moravian Geographical Reports, 20(2): 36-46.

TANDOĞAN, O., TOPÇU, B. (2018): Fear of crime among university students: A research in Namik Kemal University. International Journal of Research in Environmental Studies, 5(5): 70-76

TOMÁŠEK, J. (2010): Úvod do kriminologie: Jak studovat zločin. Havličkův Brod, Grada Publishing a.s.

TOPINKA, D., JANOUČKOVÁ, K. (2009): Výzkum rizikových faktorů souvisejících s existencí sociálně vyloučených romských lokalit ve městě Přerově. SocioFactor [online]. [cit. 2020-02-22]. Available at: https://www.socialnizaclenovani.cz/wp-content/uploads/Prerov_vyzkum rizikovych_faktoru_SVL_Sociofactor_2009_vyzkumnazprava.pdf

TUAN, Y. F. (1975): Images and mental maps. Annals of the Association of American Geographers, 65(2): 205-213.

TUAN, Y. F. (1977): Space and place. The perspective of experience. Minneapolis, London, University of Minnesota Press.

TULUMELLO, S. (2015): From "Spaces of Fear" to "Fearscapes": Mapping for Reframing Theories About the Spatialization of Fear in Urban Space. Space and Culture, 18(3): 257-272.

TULUMELLO, S. (2017): Fear, Space and Urban Planning: A Critical Perspective from Southern Europe. Springer, UNIPA Springer Series.

WEINRATH, M. (2000): Violent victimization and fear of crime among Canadian Aboriginals. Journal of Offender Rehabilitation, 30(1-2): 107-120.

WILLS, J. (2009): Environmental perception. In: Gregory, D. et al.: The Dictionary of Human Geography (pp. 202-203). Chichester, Wiley-Blackwell. 